\title{
The Effect of Water Extracts of Phyllanthus emblica and Costus speciousus on Reducing Obesity in Albino Rats
}

\begin{abstract}
Bakground: Obesity is a medical condition in which excess body fat has accumulated to the extent that it may have a negative effect on health, leading to reduced life expectancy and/or increased health problems. Obesity increases the likelihood of various diseases, particularly heart disease, type 2 diabetes, obstructive sleep apnea, certain types of cancer, and osteoarthritis.Obesity is most commonly caused by a combination of excessive food energy intake, lack of physical activity, and genetic susceptibility, endocrine disorders, medications, or psychiatric illness. Objective: This work aimed to study the effect of phyllanthus and costus aqueous extracts on inflicted obese rats. Materials and methods: Thirty mature male albino rats weighing $150 \pm 5 \mathrm{~g}$ were divided into 6 equal groups ( $n=5$ rats each); one group was kept as a negative control, while the other 5 groups were fed for four weaks on high fat diet ( $40 \%$ of calories as fat) to induce obesity, one group of them was left as positive control group (C $+v e)$ while the rest four groups were given orally two doses $(300$ and $600 \mathrm{mg} / \mathrm{kg})$ of phyllanthus and costus aqueous extracts. At the end of experimental period (28 days), blood samples were collected for serum separation to determine serum level glucose, Apolipoprotin B, liver enzymes (AST, ALT and ALP), total cholesterol, triglycerides, atherosclerosis index, lipoprotein fraction (HDLc, LDLc and VLDLc), kidney function(creatinine, urea and uric acid) and histopathological examination for the liver and heart. Results: The obtained results demonstrated that phyllanthus and costus aqueous extracts caused significant improvement in seurum glucose, liver enzymes, lipid profile, apolipoprotienA and kidney functions in inflicted obese rats. Conclusion: According to the results obtained, phyllanthus and costus aqueous extracts could be used for obese treatment and to improve vital functions of the body and weight loss.
\end{abstract}

Asmaa H. A. Ahmed ${ }^{1}$ al., 2005)
Keyword: obesity-phyllanthus - costus

\section{INTRODUCTION}

Overweight and obesity are defined as process characterized by excessive accumulation of body fat with multiple organ specific consequences that could impair health (WHO, 2011). Obesity is serious public health problem worldwide (Janghorbani et al.,2007). The increasing obesity prevalence all over the world has been attributed to industrialization and modernization which creates an obesogenic environment, encourages sedentary life style and increase calorie intake (Bell et

WHO (2003) reported that obesity has reached epidemic proportions globally, with more than 1 billion adults overweight - at least 300 million of them clinically obese - and is a major contributor to the global burden of chronic disease and disability. Often coexisting in developing countries with under-nutrition. Obesity is a complex condition, with serious social and psychological dimensions, affecting virtually all ages and socioeconomic groups.

Rani et al., (2012) stated that Costus speciosus (Family: Costaceae) is an important medicinal plant widely used in several indigenous systems of medicine for the treatment of various ailments. The rhizome of these plants are used as an alternative source for diosgenin and generally used to control diabetes. $C$. speciosus has an antioxidant activity which may be due to plant-derived antioxidants such as tannins, lignans, stilbenes, coumarins, quinones, xanthones, phenolic acids, flavones, flavonols, catechins, anthocyanins and proanthocyanins that could delay or provide protection for living organisms from damage caused by uncontrolled production of reactive oxygen species and the concomitant lipid peroxidation, protein damage, and DNA strand breaking (Jha et al., 2010).

Phyllanthus emblica Linn. (Syn. Emblica officinalis), commonly known as Indian gooseberry or amla, family Euphorbiaceae, is an important herbal drug used in unani medicine and ayurvedic systems. The plant is used both as a medicine and as a tonic to build up lost vitality and vigor. Phyllanthus emblica is highly nutritious and could be an important dietary source of vitamin C, amino acids, and minerals. The plant also contains phenolic compounds, tannins, phyllembelic acid, phyllembelin, rutin, curcum-inoids, and emblicol. All parts of the plant are used for medicinal purposes, especially the fruit, which has been used in Ayurveda as a potent rasayana and in traditional medicine for the treatment of diarrhea, jaundice, and inflammation. Various plant parts show antidiabetic, hypolipidemic, antibacterial, antioxidant, antiulcerogenic, hepatoprotective, gastroprotective, and chemopreventive properties. Its historical, etymological, morphological

${ }^{1}$ Home Economics Department, Faculty of Specific Education, Minufiya University, Egypt.

Received July 10, 2017, Accepted August 15, 2017. 
and pharmacological aspects were discussed by Krishnaveni and Mirunalini (2010).

So, this work aimed to study the effect of phyllanthus and costus aqueous extracts on inflicted obese rats

\section{MATERIALS AND METHODS \\ I- MATERIALS}

I.I. Plants: The tested plants in this study were phyllanthus and costus and they were bought as a dried plant from the local market in Egypt.

I.II. Rats: Thirty (30) mature male albino rats weighing $150 \pm 5$ g. B.Wt. were obtained from Laboratory of Animal Colony, Helwan, Egypt.

I.III. Basal diet: The basal diet was prepared according to Reeves et al., (1993). It was consisted of $20 \%$ protein (casein), $10 \%$ sucrose, $4.7 \%$ corn oil, $0.2 \%$ choline chloride, $1 \%$ vitamin mixture, $3.5 \%$ salt mixture and $5 \%$ fiber (cellulose). The remainder was corn starch. The composition of salt mixture was reported by Hegested et al., (1941) and vitamin mixture according to Campbell, (1963).

\section{II- METHODS}

\section{II.1. Preparation of plant aqueous extracts:}

The plants obtained from the Alex local market, were milled, and dried, before used. One gram of powdered Phyllanthus emblica or Costus speciosusin mixed with $100 \mathrm{ml}$ distilled water boiled for $10 \mathrm{~min}$ and then cooled for $15 \mathrm{~min}$. Thereafter, the aqueous extract was filtered using a Millipore filter (Millipore $0.2 \mathrm{~mm}$, St. Quentin en Yvelines, France) to remove particulate matter. The filtrate was then freeze-dried, and the desired dose (300 and $600 \mathrm{mg}$ of lyophilized powder of phyllanthus and costus per kg body weight of the rat) then reconstituted in $1.5 \mathrm{ml}$ of distilled water. The aqueous extracts were prepared daily, just before administration. The extracts obtained were then given orally to different groups of rats at a dose of 300 and $600 \mathrm{mg} / \mathrm{kg}$ body weight (Lemhadri et al., 2004).

\section{II.II. Phenolic compounds of phyllanthus and costus extracts:}

The Phenolic compounds of phyllanthus and costus extracts were analyzed by HPLC analysis according to (Pascale et al., 2004) at ministry of agricultural and land reclamation, agricultural Res. Center, food technology Res. Institute in Egypt.

\section{II.III. Experimental design:}

All the experiment process was done in the laboratory of Ophthalmology Hospital, Giza. Thirty Sprague-Dawley male albino rats, each weighing $150 \pm 5$ g., were housed in special cages under controlled conditions. Every day, animals were observed for the external appearance, shape, colour and distribution of hair and physical activity. All rats were fed on basal diet for 7 consecutive days before the beginning of the experiment for adaptation. Diets were presented to rats in special non-scattering feeding cups to avoid loss of feed and contamination. Tap water was provided to rats by mean of glass tubes projecting through wire cages from inverted bottles supported to one side of the cage. Rats were divided into two main groups. The first main group ( $\mathrm{n}=5$ rats) fed on basal diet and left as a negative control group. The second main group fed four weaks on high fat diet ( $40 \%$ of calories asheep tail fat) to induce obesity in rats ( Kang et al., 2005), then they were divided into five equal groups ( $5 \times 5$ rats each), one of them was left as positive control group $(\mathrm{C}+\mathrm{ve})$ while the rest four groups were orally given two doses of ( 300 and $600 \mathrm{mg} / \mathrm{kg}$ ) of phyllanthus and costus aqueous extracts individually for each of them.

\section{II.IV. Biological and biochemical evaluation}

During the experimental period, the diet consumed was recorded every day, and body weight recorded every week. The body weight gain (BWG) and feed efficiency ratio (FER) were determined according to (Chapman et al. 1959) using the following equations.

$\mathrm{BWG}=$ Final Weight-Initial weight

FER = Body weight gain (g/day)

Feed intake (g/day)

At the end of experimental period (28 days), blood samples were collected for serum separation to determine the following parameters: Serum glucose which was measured using the modified kinetic method according to Kaplan (1984) by using kit supplied by Spinreact, Spain. Serum liver enzymes ALT activity determined according to Tiez (1976). AST activity measured in serum using the modified kinetic method of Henry (1974) and ALP according to method of Moss (1982). Total cholesterol determined according to Ratliff and Hall (1973), triglycerides according to Fossati and Principe (1982), lipoprotein fractions (HDLc , LDLc and VLDLc) according to Gordon and Amer (1977) and apolipoprotein B according to (McQueen et al., 2008), provided that

\begin{tabular}{cc} 
VLDL-C concentration $\mathrm{mg} / \mathrm{dl}=$ & T.G \\
\hline
\end{tabular}

$\mathrm{LDL}=\mathrm{TC}-(\mathrm{VLDL}+\mathrm{HDL})$ and

atherogenic index $(\mathrm{AI})=\underline{\mathrm{LDL}+\mathrm{VLDL}}$

HDL

\section{- Determination of apolipoprotein B:}

Plasma lipids, lipoproteins, apoB, and apoA-I were measured. Prospective Apo lipoprotein-related mortality 
risk (AMORIS) determined according to Göran et al., (2004).

\section{- Determination of liver function:}

Aspartate transaminase (AST), aspartate aminotransferase (ASAT), alanine transaminase(ALT) and alkaline phosphatase ( ALP) were determined as the following :

\section{- Determination of alanine transaminase (ALT):}

ALT activities measured in serum using the modified kinetic method of Tietz (1976).

\section{- Determination of aspartate transferase(AST):}

AST activities were measured in serum using the modified kinetic method of Henry (1974).

\section{- Determination of alkaline phosphatase (ALP):}

ALP activities were measured in serum using the modified kinetic method or liquicolor of Moss (1982) by using kit supplied by Human, Germany.

\section{- Determination of kidneys function}

Creatinine, urea and uric acid were determined according to (Henry, 1974), (Pattn and Crouch, 1977) and (Schultz and Kaplan, 1984) respectively.

\section{II.V.Histopathological investigation :}

Liver and heart were removed, cleaned in saline solution and rinsed then kept in formalin solution for histopathological examination according to (Banchroft, et al., 1996).

\section{II.VI. Statistical analysis}

The obtained data were statistically analyzed using computerized SPSS (Statistic Program Sigma Stat, statistical soft-ware, Effects of different treatments were analyzed by one-way ANOVA (Analysis of variance) test using Duncan's multiple range test and $\mathrm{p} \leq 0.05$ was used to indicate significant differences between groups (Snedecor and Cochran, 1967).

\section{RERSULTS AND DISCUSSION}

1-Phenolic compound of costus speciosusin and phyllanthus emblica.

The main phenolic compounds identified in costus speciosusin and phyllanthus emblica are presented in Table (1). Results show that the predominant phenolic compounds in costus speciosusin were pyrogallol, evanillic, chlorogenic and salycilc (701.96, 433.47, 323.87and $94.45 \mathrm{ppm}$, respectively). Data in Table (1) show that phenolic compounds in phyllanthus emblica was higher content in pyrogallol, catechol, gallic, ellagic, P-OH benzoic, e-vanillic and catechein (59531,49, 12746.25, 8606.54, 6349.75, 4649.91, 2984.51 and $2792.83 \mathrm{ppm})$ respectively. The result reveled that phyllanthus emblica was a rich source of phenolic compounds especially pyrogallol, catechol, gallic, ellagic, $\mathrm{P}-\mathrm{OH}$ benzoic, e-vanillic and catechein. Phenols are very important plant constituents because of their scavenging ability on free radical's due to their hydroxyl groups.

These results agree with (Ekta et al.,2011) mentioned that phyllanthus emblica is rich in quercetin, phyllanthus compounds, gallic acid, tannins, flavonoids, pectin and vitamin $\mathrm{C}$ and also contains various polyphenolic compounds. A wide range of phytochemical components including terpenoids, alkaloids, flavonoids, and tannins have been shown to posses' useful biological activities.

\section{Biological evaluation}

2.1Effect of the extracts on feed intake (FI), body weight gain (BWG) and feed efficiency ratio (FER) of inflicted obese rats

Feed intake (FI) of the $(\mathrm{C}+\mathrm{ve})$ group was higher being $48.8 \pm 2.60 \mathrm{~g} /$ day compared to $23.70 \pm 1.60 \mathrm{~g} /$ day in $(\mathrm{C}-\mathrm{ve})$ rats. These results denote significant increase in FI of rats induced by high caloric diet $(+v e)$ group as compared to (C-ve) group. All rats fed with high fat and given phyllanthus and costus aqueous extract at two doses $(300,600 \mathrm{mg} \backslash \mathrm{kg})$ showed significant decrease in FI compared to $(\mathrm{C}+\mathrm{ve})$ group.

Data present in table (2) show the effect of phyllanthus and costus aqueous extracts on feed intake (FI),body weight gain (BWG) and feed efficiency ratio (FER) of experimental rats.

It could be observed concerning body weight gain (BWG), that in (C -ve) group it was $35.00 \pm 5.00 \%$ but in $(\mathrm{C}+\mathrm{ve})$ group was $45.00 \pm 3.00 \mathrm{~g}$. The obtained results showed that there was significant increase in BWG in positive control group when compared to the negative control group. All rats given phyllanthus and costus aqueous extract at two doses $(300,600 \mathrm{mg} \backslash \mathrm{kg})$ showed significant decrease $\mathrm{p}<0.05$ when compared to $(\mathrm{C}+\mathrm{ve})$ group. However, there were non-significant changes between all treated groups and (c-ve) group.

Regarding feed efficiency ratio (FER), it was found from data of the same table that $(\mathrm{C}+\mathrm{ve})$ group had FER of $0.033 \pm 0.013$ while in (C-ve) it was $0.053 \pm 0.003$. These results denote that there was a significant decrease in FER of rats of $(\mathrm{C}+\mathrm{ve})$ compared to $(\mathrm{C}$-ve) rats. All obese rats given phyllanthus and costus aqueous extract at doses $(300,600 \mathrm{mg} \backslash \mathrm{kg})$ had significant increase in (FER) as compared to control positive group while no significant changes observed when compared to control negative group.

These results agree with Savita et al., (2015) who suggested that oral Phyllanthus emblica supplementation may provide beneficial effects in 
overweight/Class-1 obese adults by lowering multiple global cardiovascular disease risk factors

\section{Biochemical analysis}

Tables from (3-6) show the effect of oral ingestion of phyllanthus and costus aqueous extracts on serum glucose, apolipoprotein B, lipid profiles (total cholesterol, triglycerides, atherosclerosis index, HDL, LDL and VLDL), liver enzymes (AST, ALT and ALP), and kidneys function (creatinine, urea and uric acid) of obese rats.

\subsection{Serum glucose and apolipoprotein $B$ :}

Data listed in table (3) demonstrated the effect of oral ingestion of phyllanthus and costus aqueous extracts on serum glucose level and apolipoprotein B on obese rats.
The result of serum glucose level showed significant increase in control positive group (c+ve) as compared to the control negative group (c-ve) which were $137.4 \pm 2.20$ and $61.2 \pm 1.20 \mathrm{mg} \backslash \mathrm{dl}$, respectively. As shown in the same table, the mean value of apolipoprotein B of control positive $(+v e)$ was higher than that of negative group which were $119.43 \pm 4.8$ and $38.66 \pm 2.44$, respectively. In addition, all treated groups indicated significant decrease when compared to control (+ve group). The best treatment found for rats fed with high fat and treated with phyllanthus at two doses of 300 and $600 \mathrm{mg} / \mathrm{kg}$ in serum level glucose, and apolipoprotein B in phyllanthus at dose of $300 \mathrm{mg} / \mathrm{kg}$ b.wt. as compared to control (+ve) group.

Table 1. Phenols components by HPLC analysis of the sample at the Institute of Food Technology Research Centre for Agricultural Research of the Ministry of Agriculture in Egypt

\begin{tabular}{lcc}
\hline Phenolic compounds & Costus speciosusin & Phyllanthus emblica \\
\hline Gallic & 5.83 & 8606.54 \\
Pyrogallol & 701.96 & 59531.49 \\
4-Amino-benzoic & 8.63 & 54.00 \\
Protocatechuic & 29.63 & 803.53 \\
Chlorogenic & 323.87 & 1764.16 \\
Catechol & 26.38 & 12746.25 \\
Catechein & 32.06 & 2792.83 \\
Caffeine & 7.48 & 158.55 \\
P-OH-benzoic & 46.99 & 4649.91 \\
Caffeic & 59.23 & 369.05 \\
Vanillic & 12.96 & 00 \\
Ferulic & 58.47 & 188.79 \\
Iso-Ferulic & 16.76 & 193.68 \\
e-vanillic & 433.47 & 2984.51 \\
Reversetrol & 30.73 & 92.24 \\
Ellagic & 24.69 & 6349.75 \\
Alpha-coumaric & 41.47 & 166.01 \\
Benzoic & 52.40 & 851.07 \\
Salycilc & 94.45 & 309.77 \\
3,4,5-methoxy-cinnamic & 9.60 & 95.29 \\
Coumarin & 7.61 & 71.56 \\
p-coumaric & 10.13 & 24.26 \\
Cinnamic & 6.23 & 214.33 \\
\hline
\end{tabular}

Table 2. Effect of Phyllanthus emblica and Costus speciosusin aqueous extracts on FI (Feed intake), BWG (Body weight gain) and FER (Feed efficiency ratio) of inflicted obese rats

\begin{tabular}{|c|c|c|c|c|c|}
\hline \multicolumn{3}{|r|}{ parameters } & FI/28day & BWGg/28day & FER(ratio) \\
\hline 1 & \multicolumn{2}{|c|}{ Control -ve } & $23.7 \pm 1.60 \mathrm{~b}$ & $35 \pm 5.00 \mathrm{~b}$ & $0.053 \pm 0.003 a$ \\
\hline 2 & \multicolumn{2}{|c|}{ Control+ve } & $48.8 \pm 2.60 \mathrm{a}$ & $45 \pm 3.00 \mathrm{a}$ & $0.033 \pm 0.013 b$ \\
\hline 3 & \multirow{2}{*}{ Phyllanthus emblica } & $300 / \mathrm{mg} / \mathrm{kg}$ & $19.7 \pm 3.20 b$ & $33 \pm 3.00 \mathrm{~b}$ & $0.06 \pm 0.01 \mathrm{a}$ \\
\hline 4 & & $600 / \mathrm{mg} / \mathrm{kg}$ & $17.5 \pm 2.30 \mathrm{c}$ & $32 \pm 2.00 \mathrm{~b}$ & $0.065 \pm 0.01 \mathrm{a}$ \\
\hline 5 & \multirow{2}{*}{ Costus speciosusin } & $300 / \mathrm{mg} / \mathrm{kg}$ & $22.8 \pm 1.80 b$ & $37 \pm 3.00 \mathrm{~b}$ & $0.058 \pm 0.007 \mathrm{a}$ \\
\hline 6 & & $600 / \mathrm{mg} / \mathrm{kg}$ & $19.8 \mathrm{v} 4.00 \mathrm{~b}$ & $35 \pm 5.00 \mathrm{~b}$ & $0.063 \pm 0.01 \mathrm{a}$ \\
\hline \multicolumn{3}{|c|}{ L. S. $(0.05)$} & 4.82 & 6.53 & 0.016 \\
\hline
\end{tabular}

Means with different letters $(a, b, c, d)$ in the same column differ significantly at $\mathrm{p} \leq 0.05$ using one-way ANOVA test, while those with similar letters denote non-significant difference. 
Table 3. Serum glocouse and apolipoprotein B of Phyllanthus emblica and Costus speciosusin of obese rats

\begin{tabular}{|c|c|c|c|c|}
\hline Groups & & Parameters & glocouse(mg\dl) & Apolipoprotien B \\
\hline 1 & \multicolumn{2}{|c|}{ Control -ve } & $61.2 \pm 1.20 \mathrm{~d}$ & $38.06 \pm 2.44 \mathrm{e}$ \\
\hline 2 & \multicolumn{2}{|c|}{ Control+ve } & $137.4 \pm 2.20 \mathrm{a}$ & $119.43 \pm 4.8 \mathrm{a}$ \\
\hline 3 & \multirow{2}{*}{ Phyllanthus emblica } & $300 / \mathrm{mg} / \mathrm{kg}$ & $61.5 \pm 1.30 \mathrm{~d}$ & $63.75 \pm 4.54 d$ \\
\hline 4 & & $600 / \mathrm{mg} / \mathrm{kg}$ & $59.2 \pm 10.10 \mathrm{~d}$ & $68.57 \pm 5.70 \mathrm{c}$ \\
\hline 5 & \multirow{2}{*}{ Costus speciosusin } & $300 / \mathrm{mg} / \mathrm{kg}$ & $67.2 \pm 4.10 \mathrm{~b}$ & $78.56 \pm 12.08 b$ \\
\hline 6 & & $600 / \mathrm{mg} / \mathrm{kg}$ & $63.4 \pm 3.00 \mathrm{c}$ & $66.3 \pm 11.97 \mathrm{c}$ \\
\hline & \multicolumn{2}{|c|}{ L. S. $(0.05)$} & 3.46 & 0.00 \\
\hline
\end{tabular}

Means with different letters $(a, b, c, d)$ in the same column differ significantly at $\mathrm{p} \leq 0.05$ using one-way ANOVA test, while those with similar letters denote non-significant difference.

These results agree with Pitchai et al., (2008) concluded the $C$. speciosus hexane extract has antihyperglycemic and hypolipidemic activity, being able to ameliorate the diabetic state, and is probably a source of hypoglycemic compounds.

Patel et al., (2010) reported that Emblica reduced lipid peroxidation and increased anti-oxidant parameters in the liver homogenates of diabetic rats. Polyphenol enriched fraction of HE (hydroalcoholic extract of Emblica) was significantly improved disarranged carbohydrate and lipid metabolism of chemically induced diabetes in rats. The mechanism of its antidiabetic activity appears to be either improvement in peripheral glucose utilization, increased insulin sensitivity, or anti-oxidant property.

Akhtar et al., (2011) reported that Emblica officinalis powder significantly $(\mathrm{P}<0.05)$ improved highdensity lipoprotein-cholesterol and lowered levels of low-density lipoprotein-cholesterol.

\subsection{Effect on total cholesterol, triglycerides, of obese} rats serum

The effect of oral ingestion of phyllanthus and costus aqueous extracts on serum levels of total cholesterol (TC), triglycerides (TG), atherosclerosis index and apolipoprotein B on rats fed on high caloric diet is recorded in table (4).

Table 4. Serum total cholesterol, triglycerides and atherogenic index of obese rats treated by Phyllanthus and Costus extracts

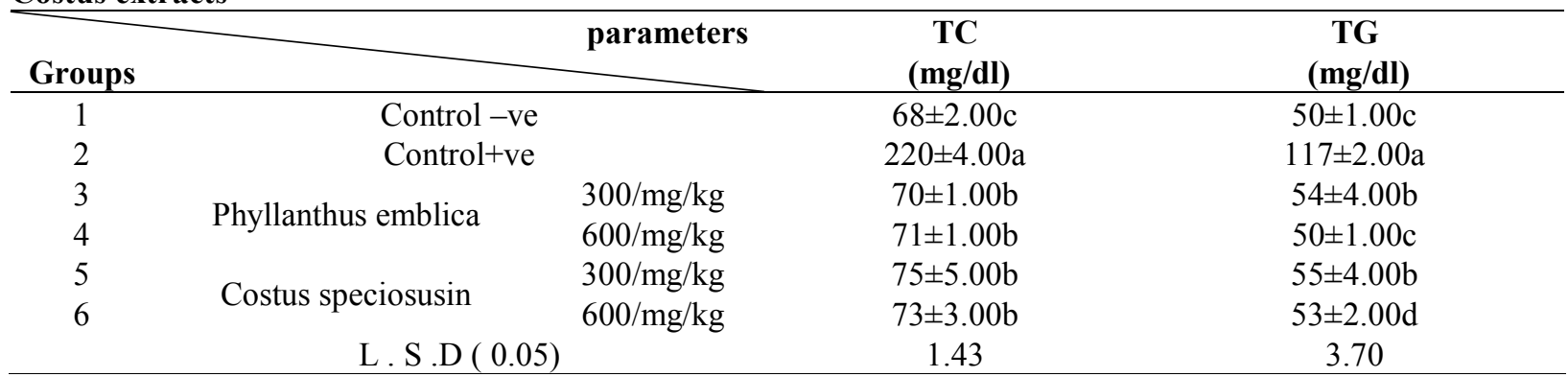

Means with different letters $(\mathrm{a}, \mathrm{b}, \mathrm{c}, \mathrm{d})$ in the same column differ significantly at $\mathrm{p} \leq 0.05$ using one way ANOVA test, while those with similar letters denote non-significant difference.
It is clear from data that in obese rats of high caloric diet without treatment $(\mathrm{C}+\mathrm{ve})$, the serum levels of total cholesterol and triglycerides were $220 \pm 4.00$ and $117 \pm 2.00 \mathrm{mg} / \mathrm{dl}$, compared to $68.00 \pm 2.00$ and $50 \pm 1.00$ $\mathrm{mg} / \mathrm{dl}$ in $(\mathrm{C}-\mathrm{ve})$ rats $(\mathrm{C}-\mathrm{ve})$, respectively. The obtained results showed significant increase in serum levels of total cholesterol and triglycerides in control positive group. All obese rats' ingested phyllanthus and costus aqueous extracts at two doses (300 and $600 \mathrm{mg} / \mathrm{kg}$ ) showed significant decrease in serum levels of total cholesterol and triglycerides as compared to $(\mathrm{C}+\mathrm{ve})$ group.

The results of table (4) are confirmed by the findings of Qureshi et al., (2009) who reported that the aqueous extract of Phyllanthus emblica also induced hypotriglyceridemia by decreasing TG levels at $0,1,2$ and 4 hours in diabetic rats $(\mathrm{p}<0.05)$. In addition, the extract was also found to improve liver function by normalizing the activity of liver-specific enzyme alanine transaminase (ALT).

Results obtained in the present work agreed with that of Bavarva and Narasimhacharya (2008) concluded that Costus speciosus root extract possesses antihyperglycemic, antihyperlipemic and antioxidative effects, which might help in the management of diabetes and its complications. 


\section{Histopathlogical Photos:}

\begin{tabular}{|c|c|c|}
\hline Groups & Heart & Liver \\
\hline Control (-ve) & $\begin{array}{l}\text { Photo 1. Heart of negative control group } \\
\text { (1) showing normal cardiac myocytes }\end{array}$ & $\begin{array}{l}\text { Photo 7. Liver of negative control -ve group showing } \\
\text { the normal histological structure of hepatic lobule }\end{array}$ \\
\hline Control (+ve) & $\begin{array}{l}\text { Photo 2. Heart of positive control group } \\
\text { (2) showing necrosis of cardiac myocytes } \\
\text { and intermuscular haemorrhage }\end{array}$ & $\begin{array}{l}\text { Shoto 8. Liver of positive control + ve group showing } \\
\text { hydropic degeneration of hepatocytes and congestion } \\
\text { of central vein and hepatic sinusoids }\end{array}$ \\
\hline $\begin{array}{l}\text { Emblica } \\
300 / \mathrm{mg} / \mathrm{kg}\end{array}$ & $\begin{array}{l}\text { Photo 4. Heart of treated group with } \\
\text { emblica 300/mg/kg (4) showing inter- } \\
\text { muscular oedema }\end{array}$ & $\begin{array}{l}\text { Photo 10. Liver of group treated with } \quad(300 \mathrm{mg}) \\
\text { showing necrosis of sporadic hepatocytes }\end{array}$ \\
\hline $\begin{array}{l}\text { Emblica } \\
600 / \mathrm{mg} / \mathrm{kg}\end{array}$ & $\begin{array}{l}\text { Photo } 3 \text {. Heart of group treated with } \\
\text { emblica } 600 / \mathrm{mg} / \mathrm{kg} \text { group (3) showing no } \\
\text { histopathological changes }\end{array}$ & $\begin{array}{l}\text { Photo 9. Liver of group treated with }(600 \mathrm{mg}) \text { showing } \\
\text { congestion of central vein and hepatic sinusoids }\end{array}$ \\
\hline $\begin{array}{l}\text { Costus } \\
300 / \mathrm{mg} / \mathrm{kg}\end{array}$ & $\begin{array}{l}\text { Photo 5. heart of group (5) treated with } \\
\text { Costus } 300 / \mathrm{mg} / \mathrm{kg} \text { showing no } \\
\text { histopathological changes }\end{array}$ & $\begin{array}{l}\text { Photo 11. Liver of group treated with (300mg) } \\
\text { showing no histopathological changes }\end{array}$ \\
\hline $\begin{array}{l}\text { Costus } \\
600 / \mathrm{mg} / \mathrm{kg}\end{array}$ & $\begin{array}{l}\text { Photo 6. heart of group (6) treated with } \\
\text { Costus } 600 / \mathrm{mg} / \mathrm{kg} \text { showing no } \\
\text { histopathological changes }\end{array}$ & $\begin{array}{l}\text { Photo 12. Liver of group treated with }(600 \mathrm{mg}) \\
\text { showing binucleation of hepatocytes }\end{array}$ \\
\hline
\end{tabular}


It was also indicated upregulating the that $P$. emblica is capable of $\mathrm{PI} 3 \mathrm{~K} / \mathrm{Akt} / \mathrm{GSK} 3 \beta / \beta$-catenin cardioprotective pathway, thereby preserving cardiac tissue during ischemia-reperfusion injury. (Thirunavukkarasu et al., 2015).

\subsection{Effect on lipoprotein fractions (HDLc, LDLc and VLDLc) and atherogenic index}

Data presented in table (5) show the effect of oral ingestion of phyllanthus and costus aqueous extracts on the levels of lipoprotein fraction (HDLc, LDLc and VLDLc) in obese rats.

It could be noticed that in $(\mathrm{C}+\mathrm{ve})$, the serum levels of HDLc, LDLc and VLDLc were $25 \pm 3.00,171.6 \pm 2.20$ and $23.4 \pm 2.30 \mathrm{mg} / \mathrm{dl}$, respectively, while in $(\mathrm{C}-\mathrm{ve})$ groups, the serum levels of the previously mentioned lipoprotein fractions were $40 \pm 2.00,18.00 \pm 1.00$ and $10.00 \pm 2.00 \mathrm{mg} / \mathrm{dl}$, respectively. These finding denote that there were significant decrease in HDLc but significant increase in LDLc and VLDLc lipoprotein fractions in the serum of obese rats without treatment as compared with the control -ve rats. All treated rats and given phyllanthus and costus aqueous extract at two doses $(300$ and $600 \mathrm{mg} / \mathrm{kg}$ ) showed significant increase in (HDL-c) and significant decrease in low and very low-density lipoprotein (LDLc and VLDLc) compared with the control +ve group. The best treatment was found for Phyllanthus emblica at dose $600 \mathrm{mg} / \mathrm{kg}$, because values of this group value were near to normal rats (-ve) with non-significant differences compared to costus speciosus $(600 \mathrm{mg} / \mathrm{kg})$ group. Regarding atherosclerosis index, there were significant increase in AI for control positive group as compared to control negative group which were $7.8 \pm 1.60$ and $0.7 \pm 0.20$, respectively. All treated groups showed significant decrease in atherogenic index when compared to control positive group.
Our results support that obtained by Jayasri, et al., (2009) who evaluated the antioxidant activity of the plant Costus pictus, where leaves and rhizomes of C. pictus showed good antioxidant activity. Their study suggested that C. pictus plant could be used as a potent source of natural antioxidants.

The ethanolic extract of Costus speciosus rhizome shows significant reduction in blood glucose, glycosylated haemoglobin, blood urea, serum uric acid, serum creatinine, triglycerides, total cholesterol, phospholipids, low density lipoprotein (LDL), very lowdensity lipoprotein (VLDL), and increase in liver glycogen, insulin and lactate dehydrogenase (LDH). Revathy et al., (2009).

In addition, Emblica officinalis may be the pivotal factor for hypolipidemic activity. Though the mechanisms differ in the two cases, the net effect is to lower lipid levels (Anila and Vijayalakshmi, 2002).

Antony et al., (2008) found a reduction in total and LDL cholesterol and enhancement of beneficial HDL cholesterol with E. officinalis in addition, blood CRP levels (A C-reactive protein (CRP) test is a blood test that measures the amount of a protein called $\mathrm{C}$-reactive protein in yourblood. C-reactive protein measures general levels of inflammation in your body), a marker for inflammation, were also significantly reduced. Since dyslipidemia and inflammation are the two major components of cardiovascular diseases, the present results must be considered encouraging and indicate the potential of Amla max in the management of heart diseases.

\subsection{Effect on liver enzymes (AST, ALT and ALP)}

Table (6) results show the effect of oral ingestion of phyllanthus and costus aqueous extracts on serum liver enzymes including aspartate amino transaminase (AST), alanine amino transferase (ALT) and alkaline phosphatase (ALP) on obese rats.

Table 5. Serum lipoprotein fractions (HDLc, LDLc and VLDLc) of obese and treated rats

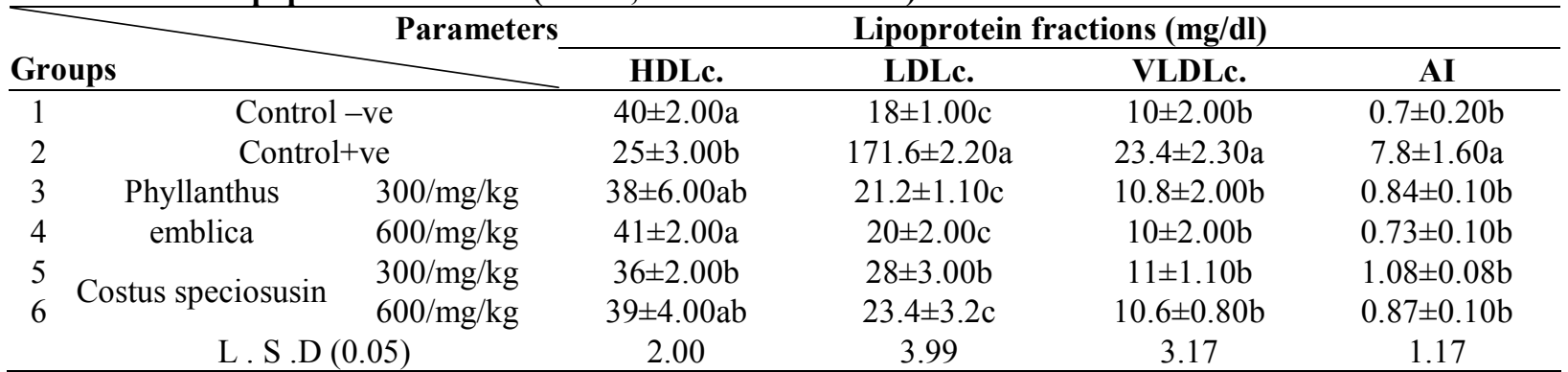

Means with different letters $(a, b, c, d)$ in the same column different significantly at $p \leq 0.05$ using one way ANOVA test, while those with similar letters denote non-significant difference. 
Table 6. Serum aspartate amino transaminase (AST), alanine amino transferase (ALT) and alkaline phosphatase (ALP) of the obese treated rats

\begin{tabular}{|c|c|c|c|c|c|}
\hline \multicolumn{3}{|c|}{$\begin{array}{ll}\text { Groups } & \text { Parameters } \\
\end{array}$} & $\operatorname{AST}(\mathbf{U} / \mathbf{L})$ & $\operatorname{ALT}(\mathbf{U} / \mathbf{L})$ & $\operatorname{ALP}(\mathbf{U} / \mathbf{L})$ \\
\hline 1 & \multicolumn{2}{|c|}{ Control -ve } & $72.4 \pm 0.50 \mathrm{~d}$ & $22.6 \pm 2.50 \mathrm{c}$ & $139.3 \pm 2.10 \mathrm{~b}$ \\
\hline 2 & \multicolumn{2}{|c|}{ Control+ve } & $150.9 \pm 2.90 \mathrm{a}$ & $28.5 \pm 2.20 \mathrm{a}$ & $212.5 \pm 0.70 \mathrm{a}$ \\
\hline 3 & \multirow{2}{*}{ Phyllanthus emblica } & $300 / \mathrm{mg} / \mathrm{kg}$ & $75 \pm 2.00 \mathrm{~cd}$ & $23.1 \pm 1.90 \mathrm{c}$ & $129.3 \pm 4.10 \mathrm{~d}$ \\
\hline 4 & & $600 / \mathrm{mg} / \mathrm{kg}$ & $71.2 \pm 1.20 \mathrm{~d}$ & $22 \pm 1.80 \mathrm{c}$ & $125.1 \pm 1.90 \mathrm{e}$ \\
\hline 5 & \multirow{2}{*}{ Costus speciosusin } & $300 / \mathrm{mg} / \mathrm{kg}$ & $82.4 \pm 2.40 \mathrm{~b}$ & $25.7 \pm 2.20 \mathrm{~b}$ & $135.2 \pm 2.20 \mathrm{c}$ \\
\hline 6 & & $600 / \mathrm{mg} / \mathrm{kg}$ & $79 \pm 4.00 \mathrm{bc}$ & $25.4 \pm 5.00 \mathrm{~b}$ & $130 \pm 1.00 \mathrm{~d}$ \\
\hline & \multicolumn{2}{|c|}{ L.S .D $(0.05)$} & 4.35 & 2.02 & 4.05 \\
\hline
\end{tabular}

Means with different letters (a, b,c,d) in the same column differ significantly at $\mathrm{p} \leq 0.05$ using one way ANOVA test, while those with similar letters denote non-significant difference.

From table (6), results inflicted that obese rats without treatment, showed serum levels of AST, ALT and ALP of $150.9 \pm 2.90,28.5 \pm 2.20$ and $212.5 \pm 0.70 \mathrm{U} / \mathrm{L}$ respectively, while in $(\mathrm{C}-\mathrm{ve})$ rats, the serum levels of the mentioned previously enzymes activities were $72.4 \pm 0.50,22.6 \pm 2.50$ and $139.3 \pm 2.10 \mathrm{U} / \mathrm{L}$, respectively. These findings indicated that there were significant increases of AST, ALT and ALP activities in the serum of obese rats as compared to $(\mathrm{C}-\mathrm{ve})$ " normal" rats $(\mathrm{p} \leq$ 0.05).

All obese rats induced by high caloric diet and given phyllanthus and costus aqueous extract at two doses showed significant decreases $(p<0.05)$ in serum levels of AST, ALT and ALP activities when compared to control positive group. It is evident that the best treatment was that of phyllanthus extract at dose $600 \mathrm{mg} / \mathrm{kg}$ because this dose caused the highest decrease in serum liver enzymes activities when compared to obese rats $(+v e)$.

These results agree with that of Nitin and Khosa, (2009) who used the extract of the rhizomes of Costus speciosus and found a significant fall in the levels of serum glutamyl oxalacetic acid transaminase (SGOT), serum glutamyl pyruvate transaminase (SGPT), alkaline phosphatase (ALKP), serum bilirubin (SBLN) and liver inflammation supported by histopathological studies on liver, thus exhibited a significant hepatoprotective activity.

Wang et al., (2008) stated that certain herbs extracts would be hopefully developed as a new sort of natural antioxidant and radical scavenging agent.

\subsection{Effect on kidney function (Creatinine, Urea and Uric acid)}

Table (7) shows the effect of oral ingestion with phyllanthus and costus aqueous extracts on kidney function (Creatinine, Urea and Uric acid) in obese rats.

The serum levels of the mentioned previously parameters were $0.32 \pm 0.01,21.1 \pm 2.50$ and $1.36 \pm 0.94$ $\mathrm{U} / \mathrm{L}$ in negative control group rats $(\mathrm{C}-\mathrm{ve})$, while in positive control group $(\mathrm{C}+\mathrm{ve})$ the mean values were $0.5 \pm 0.20,36.5 \pm 3.70$ and $3.62 \pm 1.09 \mathrm{U} \backslash \mathrm{L}$ respectively. These findings denote that there were significant increases in serum levels of creatinine, urea and uric acid of rats $(\mathrm{C}+\mathrm{ve})$ as compared to $(\mathrm{C}-\mathrm{ve})$ normal rats $\mathrm{p}<0.05$. Phyllanthus aqueous extract at a dose of $600 / \mathrm{mg} / \mathrm{kg} \mathrm{B}$. Wt., group showed the highest significant improvement in creatinine, urea and uric acid when compared to most of other tested groups. This group was also the best for other parameters (Table 2, 3, 4, 5 and 6).

Table 7. Serum Creatinine, Urea and Uric acid of obese treated rats

\begin{tabular}{|c|c|c|c|c|c|}
\hline \multicolumn{2}{|c|}{ Groups } & Parameters & Creatinine (U/L) & Urea (U/L) & Uric Acid (U/L) \\
\hline 1 & \multicolumn{2}{|c|}{ Control -ve } & $0.32 \pm 0.01 \mathrm{~d}$ & $21.1 \pm 2.50 \mathrm{c}$ & $1.36 \pm 0.94 c$ \\
\hline 2 & \multicolumn{2}{|c|}{ Control+ve } & $0.5 \pm 0.20 \mathrm{a}$ & $36.5 \pm 3.70 \mathrm{a}$ & $3.62 \pm 1.09 \mathrm{a}$ \\
\hline 3 & \multirow{2}{*}{ Phyllanthus emblica } & $300 / \mathrm{mg} / \mathrm{kg}$ & $0.27 \pm 0.02 \mathrm{e}$ & $20.3 \pm 3.00 \mathrm{c}$ & $1.38 \pm 0.10 \mathrm{~b}$ \\
\hline 4 & & $600 / \mathrm{mg} / \mathrm{kg}$ & $0.25 \pm 0.10 \mathrm{e}$ & $18.2 \pm 2.10 \mathrm{~d}$ & $1.35 \pm 0.10 \mathrm{c}$ \\
\hline 5 & \multirow{2}{*}{ Costus speciosusin } & $300 / \mathrm{mg} / \mathrm{kg}$ & $0.35 \pm 0.05 c$ & $23.5 \pm 2.5 b$ & $1.4 \pm 0.60 \mathrm{~b}$ \\
\hline 6 & & $600 / \mathrm{mg} / \mathrm{kg}$ & $0.39 \pm 0.10 \mathrm{~b}$ & $21 \pm 3.00 \mathrm{c}$ & $1.39 \pm 0.10 \mathrm{~b}$ \\
\hline & L.S.D & $.05)$ & 0.03 & 2.06 & 1.03 \\
\hline
\end{tabular}

Means with different letters $(\mathrm{a}, \mathrm{b}, \mathrm{c}, \mathrm{d})$ in the same column differ significantly at $\mathrm{p} \leq 0.05$ Using one way ANOVA test, while those with similar letters denote non-significant difference. 


\section{Histopathological results:}

The Histopathological structure of (heart and liver) revealed changes due to hyperclosterolemia, while feeding on diets containing the Phyllanthus emblica and Costus speciosusin (photos, 1-10) caused some improvement. This was in agreement with the histological and biochemical changes table (1-7). It seems possible that to obtain complete recovery of the original structure of heart and liver requires for more time of feeding with extracts.

\section{CONCLUSION}

According to the results obtained, phyllanthus and costus aqueous extracts could be used for obese treatment and to improve vital functions of the body and weight loss.

\section{REFERENCES}

Akhtar, M.S., A.Ramzan, Ali, A., and Ahmad, M .2011.Effect of amla fruit (Emblica officinalis Gaertn.) on blood glucose and lipid profile of normal subjects and type 2 diabetic patients.J.FoodSci Nutr. , 62(6): 609-16.

Anila,L.and N.R Vijayalakshmi. 2002. Flavonoids from Emblica officinalis and Mangifera indica effectiveness for dyslipidemia, Journal of Ethnopharmacology, 79, (1):, 8187.

Antony, B., M.Benny, and T. N. B. Kaimal . 2008.A Pilot clinical study to evaluate the effect of Emblica officinalis extract (Amla max ${ }^{\mathrm{TM}}$ ) on markers of systemic inflammation and dyslipidemia.Indian Journal of Clinical Biochemistry, 23, (4): 378-381.

Banchroft, J. D., Stevens, A. and Turner, D. R. 1996.Theory and Practice of Hitological Techniques. Fourth Ed., Churchil Livingstone, New York, London, San Francisco, Tokyo.

Bavarva, J. H. and A. V. R. L.Narasimhacharya. 2008.Antihyperglycemic and hypolipidemic effects of Costus speciosus in alloxan induced diabetic rats.J.of Phytotherapy Research, 22(5): 620-626.

Bell C.G., A.J. Walley and P. Froguel .2005.The genetics of human obesity. Nat. Rev. Genet, 6:221-234.

Campbell, J. A. 1963. Method for Determination of PER and NPR, In Evaluation of Protein Quality. Publication No. 1100 NAS-NRC, Washington, D.C. 31.

Champman, D. G., R.Gastilla, and J.A. Cambell. 1959. Evaluation of protein in food.LA. method for the determination of protein efficiency ratio. Can. J.Biochem. Phosiol.,37:679-686.

Ekta, S., Sh. Sheel, P. Ashutosh, D. Jaya, Y. Sachdev, and Sh. Swapnil. 2011.Phytochemistry, traditional uses and cancer chemopreventive activity of Amla (Phyllanthus emblica): The Sustainer, J. Applied Pharmaceutical Science 02 (01), 176-183.
Fossati, P. and L. Principe. 1982. Determination of triglycerides. Clinical Chemistry, 28: 2077-2078.

Göran ,W., J. Ingmar, H. A. Are, H. Ingar., D. F. Curt, and D. S. Allan. 2004. The apoB/apoA-I ratio is better than the cholesterol ratios to estimate the balance between plasma proatherogenic and antiatherogenic lipoproteins and to predict coronary risk, 42(12) :1355-1363, ISSN (Online) $1437-4331$.

Gordon, T., and M. Amer, 1977. Determination of HDL. J. of Med., 62: 707.

Hegested, D.M., R.C.Mills, C.A. Elvehjem, and E.B. Hart. 1941. Choline in nutrition of chicks. J. Boil. Chem., 138: 459-470, ISSN: 0021-9258.

Henry, R. J. 1974. Clinical Chemistry: Principal and Techniques. 2nd Published by Harper and Row. New York.

Janghorbani, M., M.Amini, W.Willett, M.Gouya, A.Delavari, S. Alikhani, and A. Mahdavi. 2007. First nationwide survey of prevalence of overweight, underweight, and abdominal obesity in Iranian adults. Obesity; 15:27972808 .

Jayasri, M. A., M. Lazar and A. Radha. 2009. A report on the antioxidant activity of leaves and rhizomes of Costus pictus D. Don. International Journal of Integrative Biology. 5(1):20-26.

Jha, M.K., M.B. Alam, M.S.Hossain, and A. Islam. 2010. Invitro antioxidant and cytotoxic potential of Costus speciosus (Koen.) Smith rhizome, J. Pharm. Sci. Res., 1: 138-144.

Kang, S. A., K. H. Jang, K.Hong, S.Kim, M. K.Kim, I. Y. Lee, and Y. H. Lim. 2005.Effect of Yeast beta-glucan on serum lipids and leptin levels in the diet -induced obese rats. Asia Pac. J. Clin.Nutr.,14: SII4.

Kaplan, L. A. 1984. Clinical Chemistry. The C.V. Mosby Co. St. Louis. Toronto. Princeton., 1032-1036.

Krishnaveni, M. and S. Mirunalini. 2010.Therapeutic potential of Phyllanthus emblica (amla): The ayurvedic wonder. J. Basic Clin. Physiol. Pharmacol. ,21(1):93-105.

Lemhadri A., N. A. Zeggwagh, M. Maghrani, H. Jouad, and M. Eddouks. 2004.Inhibition of endogenous glucose production accounts for hypoglycaemic effect of Spergularia purpurea in diabetic mice. J. of Ethnopharmacology, 92(2-3): 251-256.

McQueen, M.J., S. Hawken, X. Wang, S. Ounpuu, A.Sniderman, J P. robstfield, K. Steyn, J.E. Sanderson, M .Hasani, E. Volkova, K .Kazmi, and S. Yusuf. 2008. Lipids, lipoproteins, and apolipoproteins as risk markers of myocardial infarction in 52 countries (the INTERHEART study): A case-control study. Lancet, 372 (9634): 224-33.

Moss, D. W. 1982. Alkaline Phosphates Isoenzyymes. Clin.Chem ., 28: 2007-2016. 
Nitin, v. and R. L. Khosa. 2009. Evaluation of protective effects of ethanolic extract of Costus speciosus (Koenig) Sm. Rhizomes on carbon tetrachloride induced hepatotoxicity in rats. Natural product radiance, vol. 8(2), pp 123-126.

Pascale, G., H. Mireille, B.Patrick, and J. A. Marie.1999. Antioxidant composition and activity of barley (Hordeum vulgare) and malt extracts and of isolated phenolic compounds. 79: 1625-1634.

Patel, S.S., R.K. Goyal, R.S. Shah, P. R. Tirgar, P.D. Jadav, and Ayu. 2013. Experimental study on effect of hydroalcoholic extract of Emblica officinalis fruits on glucose homeostasis and metabolic parameters, Oct;34(4):440-4.

Pattn, C. J., and S. R. Croush. 1977. Enzymatic determination of urea. J. of Anal. Chem., (230): 464-469.

Pitchai, D., E. James, and I.Savarimuthu. 2008. Influence of Costus speciosus (Koen.) Sm. Rhizome Extracts on Biochemical Parameters in Streptozotocin Induced Diabetic Rats, Journal of Health Science. 54(6): 675-681.

Qureshi, S. A., A. Warda, and S. Viqar. 2009. The effect of Phyllantus emblica Linn on type-II diabetes, triglycerides and liver-specific enzyme. Pakistan Journal of Nutrition, 8(2):125-128.

Rani, A.S., G. Sulakshana, and S. Patnaik. 2012. Costus speciosus, an antidiabetic plant - Review. J, Pharm. Res, 1: $52-53$.

Ratliff, C. R. and F. Hall. 1973. A New Method for Direct Colorimetric Determination of Serum Cholesterol. Lab. Manual of Clinical Biochemistry. Scoot and White Memorial Hospital Publications. Temple. TX. USA.

Reeves, D.W., P.L. Mask, C.W. Wood, and D.P. Delaney.1993. Determination of wheat nitrogen status with a hand-held chlorophyll meter: Influence of management practices. J. Plant Nutri., 109 (16): 781-796.
Revathy, J., S. Abdullah, and S.P. Kumar. 2009.Antidiabetic effect of Costus Speciosus rhizome extract in alloxan induced albino rats. Journal of chemistry and biochemistry. 2(1): 13-22.

Savita, K., Das. Amitava, S. James, R.Cameron, and R. Sashwati .2015. Supplementation of a Standardized Extract from Phyllanthus emblica Improves Cardiovascular Risk Factors and Platelet Aggregation in Overweight/Class-1 Obese Adults. 18(4): 415-420.

Schultz, A., and A .Kaplan. 1984. Uric acid: Clin Chem. Mosby Co. St. Louis Toronto. Princeton, 1261, 1266 and 418.

Snedecor, G. W. and W. G. Cochran. 1967. Statistical Methods. 6th Ed. Iowa State University Press. Ames. Lowa. USA.

Srivastava, Shruti, Singh, Pradeep, Mishra, Garima, K. K. Jha, and R. L. Khosa, .2011. Costus speciosus (Keukand): A review. Der Pharmacia Sinica, 2 (1): 118.

Thirunavukkarasu, M., V.2. Selvaraju, L. Tapias, J.A Sanchez, J. A. Palesty, and N. Maulik . 2015. Protective effects of Phyllanthus emblica against myocardial ischemia-reperfusion injury: the role of PI3kinase/glycogen synthase kinase $3 \beta / \beta$-catenin pathway. J. Physiol Biochem. ,71(4):623-33.

Tietz, N. W. 1976. Fundamental of Clinical Chemistry. Philadelphia, W.B. Saunders.

Wang, Y. M., J. Chen, D. M. Wu, M. Xu, and Z. Wu. 2008. Primary study on antioxidative and radical scavenging activities of extracts from Phyllanthus emblica L. bark, Chemistry and Industry of Forest Products; 28(1):11-15. 19.

World health organization (WHO).2003. Global Strategy on Diet, Physical. Activity and Health: Obesity and Overweight.

World health organization (WHO) .2011. Fact Sheet: Obesity and Overweight, FS311. 


\section{الملخص العربي - ا}

\section{تأثير المستخلصات المائية للأملج والقسط الهندي على خفض السمنة في ذكور الفئران البيضاء} أسماء حسن عبد العظيم أحمد

الحرارية من دهون ليه الخروف) لحدوث السمنة فى

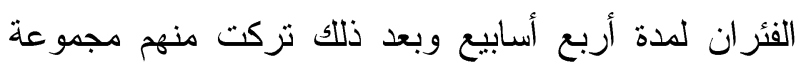
واحدة كمجوعة ضابطة موجبة فى حين أعطيت

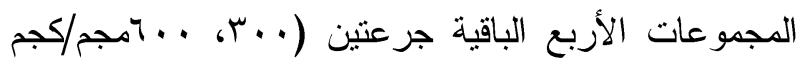
من وزن الجسم) من مستخلص الأملج و القسط الهندي. وفى التى الته

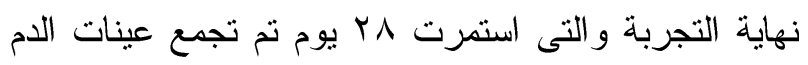

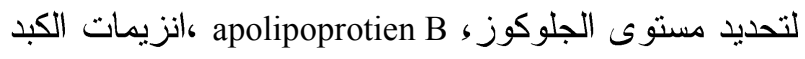
والكوليسترول الكلى والدهون الثلاثية ومؤشر تصلب الثرايين فضدا عن(HDL,LDL,VLDL) ووظائف الكلى كما أجرى فحص لأنسجة الكبد و القلب.

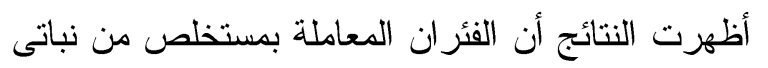

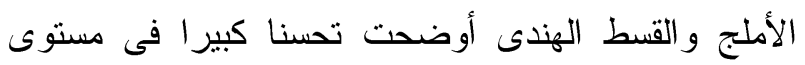
الجلوكوز و انزيمات الكبد ومستوى الدهون ووظائف الكلى الكي فى الفئران المصابة بالسمنة، ولذلك وفقا للنتائج يمكن الحث

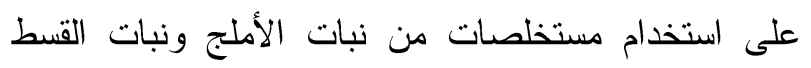
الهندي لتحسين الوظائف الحيوية للمصابين بالسمنة وخاصة

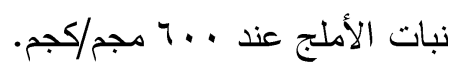

السمنة هى حالة تراكم الدهون بالجسم مما يكون لها أثر سلبي على الصحة وانخفاض متوسط العمر فضلا عن زيادة المشاكل الصحية حيث أنها تزيد من احتمال الاصابة الصنا بمختلف الأمراض وخاصة أمراض القلب و والسكرى و انقطاع التنفس الانسدادى أثناء النوم فضلا عن أنو اعن معينة من السرطان و التهاب مفاصل العظام. من مسببات السمنة الأكثر شيو عا تتضمن الافر اط فى تناول الطاقة الغذائية وقلة

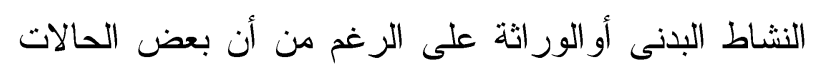

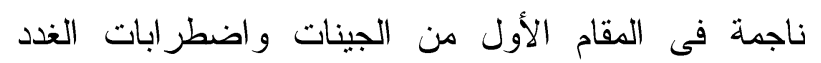

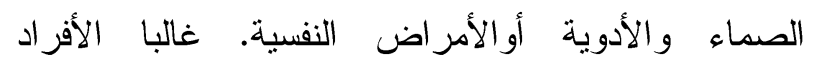
الدصابون بالسمنة يتناولون من الطاقة تفوق الطاقة اللازمة

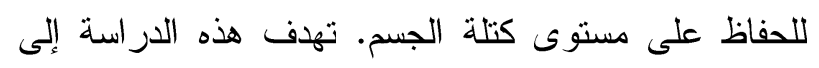

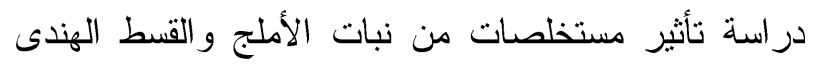
على الفئران المصابة بالبدانة المفرطة. استخدمت ذكور

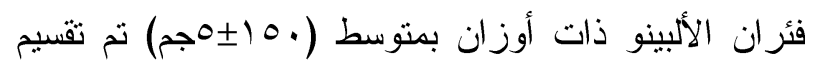
الفئران إلى 1 مجمو عات منساوية (ن= ه فئران لكل منها)

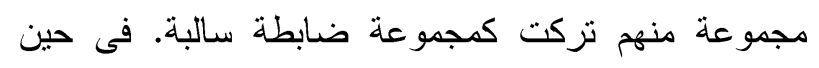

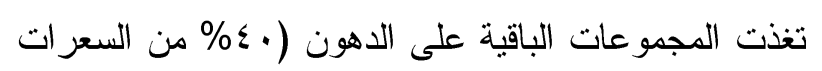

